DOI: https://doi.org/10.24127/ajpm.v8i1.1894

\title{
PROBLEM BASED LEARNING (PBL) - QR-CODE DALAM PENINGKATAN HASIL BELAJAR MATEMATIKA PESERTA DIDIK
}

\author{
Nurul Farida ${ }^{1}$, Hasanudin $^{2}$, Nurain Suryadinata ${ }^{3}$ \\ ${ }^{1,3}$ Pendidikan Matematika, Universitas Muhammadiyah Metro \\ ${ }^{2}$ SMAN 1 Kotagajah, Lampung Tengah \\ E-mail: nurulfaridamath@gmail.com ${ }^{1)}$ \\ nurain.suryadinata@gmail.com $^{31}$
}

Received 27 February 2019; Received in revised form 8 April 2019; Accepted 10 May 2019

\begin{abstract}
The purpose of this research is to improve students mathematics learning outcome through Problem Based Learning (PBL) with QR-Code on MIPA class grade X SMA Negeri 1 Kotagajah (Senior High School in Kotagajah). This research is Action Research Class. The subject on this research is 36 Students. This research is siklus research with Kemmis and Mc Taggart Models consisting of: (1) planning; (2) implementation; (3 observation; and (4) reflection. Data collection technique is using in this research is tes. Based on research result, then obtained the conclusion is Problem Based Learning with QR-code can improve students mathematics learning outcome on MIPA Class grade X SMA Negeri 1 Kotagajah. This matter showed percentage value on first cyclus is 47,22\% and increase on second cyclus to be $63,89 \%$.
\end{abstract}

Keywords: learning outcome; problem based leraning; QR-code.

\section{PENDAHULUAN}

Undang-Undang No. 20 Tahun 2003 di Indonesia menjelaskan bahwa pendidikan merupakan usaha sadar dan terencana untuk mengembangkan segala potensi yang dimiliki peserta didik melalui proses pembelajaran. Pendidikan bertujuan untuk mengembangkan potensi anak agar memiliki kekuatan spiritual keagamaan, pengendalian diri, berkepribadian, memiliki kecerdasan, berakhlak mulia, serta memiliki keterampilan yang diperlukan sebagai anggota masyarakat dan warga negara. Berdasarkan definisi tersebut tentu saja sangatlah penting adanya pendidikan di suatu negara. Lebih lanjut dijelaskan bahwa proses pendidikan berujung kepada pembentukan sikap, pengembangan kecerdasan atau intelektual, serta pengembangan keterampilan anak sesuai dengan kebutuhan (Sanjaya, 2010).
Salah satu cara untuk memberikan pendidikan kepada masyarakat adalah melalui sekolah. Di sekolah, peserta didik diberikan mata pelajaran yang beragam dan tentu saja dapat bermanfaat untuk kehidupan di masyarakat. Perkembangan pendidikan melalui sekolah dari tahun ke tahun terus mengalami perubahan dan perkembangan. Salah satu perkembangan yang terjadi adalah terkait penggunaan teknologi di sekolah. Isu baru yang muncul dan menjadi ramai diperbincangkan adalah bagaimana Ilmu Pengetahuan dalam Teknologi (IPTEK) dapat mengubah wajah dunia pendidikan yang lebih berkemajuan dan dapat mengubah pola pikir manusia lebih bijaksana dan mencerdaskan dari berbagai aspek (Iswan dan Herwina, 2018).

Perkembangan teknologi ini tidak terlepas dari adanya revolusi industri 4.0. Menurut Priatmoko (2018), revolusi industri sendiri dapat diartikan 
sebagai suatu perubahan dalam proses produksi yang berlangsung cepat. Hingga saat ini revolusi industri dianggap telah memasuki fase keempat atau 4.0 yang menghadirkan digitalisasi dan otomatisasi perpaduan internet dengan manufaktur (Suwardana, 2018). Lebih lanjut dijelaskan oleh Iswan dan Herwina (2018) bahwa kehidupan anak sekarang dihadapkan pada suasana keluarga, suasana teman sebaya, dunia maya dalam era millenial 4.0, sekolah dalam era revolusi industri, dan suasana masyarakat yang majemuk dan tingkat pemikirannya lebih kritis.

Salah satu mata pelajaran yang diberikan kepada peserta didik di sekolah adalah matematika. Mata pelajaran ini adalah mata pelajaran yang selalu diberikan baik dari pendidikan dasar, pendidikan menengah bahkan sampai dengan pendidikan tinggi. Meskipun demikian pembelajaran matematika di sekolah tidak terlepas dari kendala atau masalah tertentu, baik dari peserta didik, guru, model pembelajaran, fasilitas sekolah, media pembelajaran dan sebagainya (Kintoko,. Sujadi, I., \& Dewi, 2015; Widyatiningtyas, Kusumah, Sumarmo, \& Sabandar, 2015; dan Novita, Prahmana, Fajri, \& Putra, 2018).

Permasalahan dalam pembelajaran matematika juga ditemukan di SMAN 1 Kotagajah. SMAN 1 Kotagajah merupakan salah satu sekolah menengah atas yang berada di kabupaten Lampung Tengah Provinsi Lampung. Berdasarkan hasil prasurvey di sekolah tersebut, salah satunya dengan memberikan soal pretes di kelas X MIPA 3 diperoleh data pada Tabel 1.
Tabel 1. Hasil Pretes di Kelas X MIPA 3

\begin{tabular}{cccc}
\hline KKM & Keterangan & $\begin{array}{c}\text { Jumlah } \\
\text { Peserta } \\
\text { Didik }\end{array}$ & Persentase \\
\hline$\geq 70$ & Tuntas & 5 & $13,89 \%$ \\
$<70$ & $\begin{array}{c}\text { Tidak } \\
\text { Tuntas }\end{array}$ & 31 & $86,11 \%$ \\
& & $\mathbf{3 6}$ & $\mathbf{1 0 0 \%}$ \\
\hline
\end{tabular}

Pada data di Tabel 1 diketahui bahwa kemampuan peserta didik untuk matematika masih belum sesuai harapan yaitu masih banyak peserta didik yang belum mencapai ketuntasan dengan KKM 70. Dari hasil diskusi dengan guru matematika di SMAN 1 Kotagajah diperoleh informasi bahwa guru belum banyak menggunakan media yang berupa TIK (Teknologi Informasi dan Komunikasi). Media yang sudah digunakan baru sekedar power point yang digunakan untuk presentasi. Padahal dalam kurikulum 2013 dianjurkan guru untuk memanfaatkan TIK untuk meningkatkan kualitas pembelajaran. Menurut Marzoan (2014), dalam Kurikulum 2013 terdapat beberapa perubahan, salah satu yang terkait dengan peran TIK adalah dihapusnya mata pelajaran TIK dan sebagai penggantinya TIK menjadi alat bantu guru dalam proses pembelajaran pada semua mata pelajaran.

Fasilitas di SMAN 1 Kotagajah sebenarnya sudah cukup lengkap termasuk hal-hal terkait teknologi seperti proyektor, komputer dan termasuk akses internet. SMAN 1 Kotagajah juga membolehkan peserta didik yang ingin membawa smartphone, hanya saja penggunaannya masih dalam pengawasan pihak sekolah. Penggunaan smartphone juga dikendalikan guru pada saat di kelas. Artinya smartphone tersebut dapat digunakan ketika memang guru ingin menggunakan smartphone di dalam pembelajaran. 
DOI: https://doi.org/10.24127/ajpm.v8i1.1894

Berdasarkan permasalahan tersebut maka dirasakan perlu dilakukan penelitian untuk meningkatkan hasil belajar matematika peserta didik dengan memanfaatkan suatu teknologi tertentu sebagai sumber belajar atau media pembelajaran. Upaya pemecahan permasalahan pendidikan terutama masalah yang berhubungan dengan kualitas pembelajaran, dapat ditempuh dengan cara penggunaan berbagai sumber belajar dan penggunaan media pembelajaran yang berfungsi sebagai alat bantu dalam meningkatkan kadar hasil belajar peserta didik (Anshori, 2018).

Teknologi yang akan digunakan yaitu dengan memanfaatkan internet dan smartphone peserta didik. Untuk menjembatani hal tersebut maka dipilih untuk penggunaan $Q R$-Code. Dalam situs WwW.qr-code-generator.com dijelaskan bahwa QR merupakan singkatan dari Quick Response yang dapat mengakses informasi secara cepat dengan memanfaatkan kode yang diberikan. QR-Code adalah image dua dimensi yang merepresentasikan suatu data, terutama data berbentuk teks (Mustakim, Walanda, \& Gonggo, 2013). Penggunaan QR-Code ini diharapkan dapat lebih mempercepat peserta didik untuk dapat memperoleh suatu informasi terkait dengan materi yang diajarkan. QR-Code benar-benar sesuai dengan tren perkembangan pendidikan khususnya pembelajaran yang berpusat pada peserta didik (student-centered). QR-Code memiliki potensi bagus untuk diintegrasikan ke dalam kurikulum (Sharma, 2013).

Untuk membuat dokumen atau file lainnya yang disematkan menjadi $Q R$-Code, dapat menggunakan software (perangkat lunak) yang tersedia gratis di internet (Wayase, 2015). Dijelaskan juga bahwa beberapa langkah yang dapat dilakukan untuk membuat $Q R$ -
Code dan penggunaannya yaitu sebagai berikut.

1. Untuk menyandikan teks/SMS/URL/Kontak yang diperlukan ke $Q R$-Code, dapat menggunakan beberapa freeware offline atau situs web yang tersedia secara online yang dapat menghasilkan $Q R$-Code.

2. Masukkan informasi yang diusulkan ke dalam Generator atau pembuat $Q R$-Code.

3. Generator atau pembuat $Q R$ Code akan menghasilkan contoh $Q R$-Code seperti pada Gambar 1

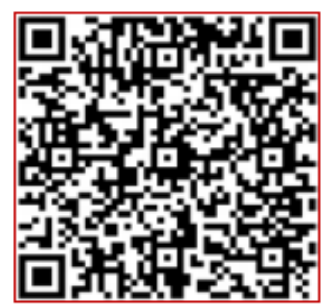

Gambar 1. Contoh $Q R$-Code

4. Simpan file gambar yang dihasilkan (QR-Qode) dan beri label.

5. Cantumkan file gambar yang disimpan ke dalam setiap perangkat presentasi atau pembelajaran seperti presentasi power point, lembar kerja, buku kerja, dll.).

6. Pengguna android perlu menginstal aplikasi untuk dapat mengakses $Q R$-Code tersebut dari google play store ke perangkat seluler.

7. Untuk mengakses atau membaca QR-Code, dapat dengan mengarahkan perangkat seluler ke area $Q R$-Code dan teks/URL atau file lainnya akan otomatis ditampilkan. (Wayase, 2015)

Untuk lebih menunjang keberhasilan penelitian ini, dipilih juga suatu model pembelajaran yang sesuai untuk dikombinasikan dengan 
penggunaan $Q R$-Code serta model pembelajaran yang sesuai dengan tuntutan kurikulum 2013. Salah satu model pembelajaran yang dirasa sesuai adalah Problem Based Learning (PBL). Problem Based Learning (PBL) atau pembelajaran berbasis masalah merupakan sebuah model pembelajaran yang menyajikan masalah kontekstual sehingga merangsang siswa untuk belajar. Dalam kelas yang menerapkan pembelajaran berbasis masalah, siswa bekerja dalam tim untuk memecahkan masalah dunia nyata (BPSDMPK, PMP, \& Kemendikbud, 2014). Lebih lanjut gambaran mengenai sintaks PBL dijelaskan pada Tabel 2. (Hosnan, 2014).

Tabel 2. Sintaks PBL

\begin{tabular}{l}
\multicolumn{1}{c}{ Tahap } \\
\hline Tahap 1 \\
Mengorientasikan peserta didik \\
terhadap masalah
\end{tabular}

\section{Tahap 2}

Mengorganisasi peserta didik untuk belajar

\section{Tahap 3}

Membimbing penyelidikan individual maupun kelompok

\section{Tahap 4 \\ Mengembangkan dan menyajikan hasil karya}

\section{Tahap 5}

Menganalisis dan mengevaluasi proses pemecahan masalah

\section{Aktivitas Guru dan Peserta Didik}

Guru menjelaskan tujuan pembelajaran dan sarana atau logistik yang dibutuhkan. Guru memotivasi peserta didik untuk terlibat dalam aktivitas pemecahan masalah nyata yang dipilih atau ditentukan

Guru membantu peserta didik mendefinisikan dan mengorganisasi tugas belajar yang berhubungan dengan masalah yang sudah diorientasikan pada tahap sebelumnya

Guru mendorong peserta didik untuk mengumpulkan informaso yang sesuai dan melaksanakan eksperimen untuk mendapatkan kejelasan yang diperlukan untuk menyelesaikan masalah.

Guru membantu peserta didik untuk berbagi tugas dan merencanakan atau menyiapkan karya yang sesuai sebagai hasil pemecahan masalah dalam bentuk laporan, video, atau model.

Guru membantu peserta didik untuk melakukan refleksi atau evaluasi terhadap proses pemecahan masalah yang dilakukan.
Pada dasarnya sudah cukup banyak penelitian yang mengkaji tentang dampak PBL terhadap peserta didik khususnya pada mata pelajaran matematika. Rata-rata hasil penelitianpenelitian tersebut menyimpulkan bahwa PBL memberikan dampak positif terhadap kemampuan matematika peserta didik (Padmavathy \& Mareesh.K (2013); Widyatiningtyas et al., (2015); Botty, Shahrill, Chong, Li, \& Jaidin (2016)). Namun demikian penelitian-penelitian lainnya masih perlu dilakukan khususnya dalam mengkombinasikan PBL dengan pembelajaran lain atau dengan komponen lainnya, salah satunya adalah dengan mengkombinasikan PBL dan penggunaan $Q R$-Code. Hal ini juga dapat menjadi solusi lain dalam memilih suatu model pembelajaran yang dengan memanfaatkan teknologi yang semakin berkembang. Penggunaan QR-Code diharapkan dapat memudahkan guru dalam menyampaikan permasalahan yang digunakan di pembelajaran PBL. Guru hanya perlu mencari permasalahan yang 
akan diangkat dalam materi pelajaran kemudian menuangkannya dalam $Q R$ Code sehingga peserta didik dapat dengan mudah dan cepat mendapatkan informasinya.

Kombinasi antara PBL dengan QR-Code diharapkan dapat meningkatkan hasil belajar matematika peserta didik. PBL merupakan pembelajaran yang menampilkan suatu masalah dunia nyata yang disesuaikan dengan materi yang akan dipelajari peserta didik, di mana permasalahan tersebut perlu diselesaikan peserta didik dengan menggunakan konsep yang dipelajari. Penggunaan $Q R$-Code akan dapat lebih mempercepat peserta didik dalam mengakses masalah yang diberikan atau juga informasi-informasi terkait penyelesaian masalah tersebut. Peserta didik akan dapat memanfaatkan internet untuk mengakses informasi namun tetap dibatasi oleh guru melalui pemanfaatan $Q R$-Code tersebut sehingga pencarian informasi oleh peserta didik tidak terlalu lama dan tepat sasaran. Penelitian ini diharapkan juga dapat memberikan gambaran tentang penggunaan salah satu teknologi di dalam pembelajaran matematika di Sekolah. Secara umum tujuan penelitian ini adalah untuk meningkatkan hasil belajar matematika peserta didik melalui Problem Based Learning (PBL) berbantuan $Q R$-Code di kelas X MIPA 3 SMA Negeri 1 Kotagajah.

\section{METODE PENELITIAN}

Penelitian ini merupakan penelitian tindakan kelas (PTK) yang dilakukan di SMA Negeri 1 Kotagajah Kabupaten Lampung Tengah Provinsi Lampung. Kelas yang digunakan untuk penelitian adalah kelas $\mathrm{X}$ MIPA 3 dengan subyek sebanyak 36 peserta didik. Penelitian ini merupakan penelitian yang bersiklus dengan setiap siklus ditargetkan menyelesaikan satu Kompetensi Dasar (KD) yang terdiri dari empat pertemuan dan kemudian dilakukan tes di setiap akhir siklus. Model yang digunakan adalah model Kemmis dan Mc Taggart (Suharsimi, 2010) yang terdiri dari empat tahap yaitu: (1) perencanaan; (2) pelaksanaan; (3) pengamatan; dan (4) refleksi. Teknik pengumpulan data yang digunakan dalam penelitian tindakan kelas ini adalah teknik tes. Teknik tes digunakan untuk mendapatkan data hasil belajar matematika peserta didik. Instrumen yang digunakan pada penelitian ini adalah lembar soal hasil belajar matematika. Target ketercapaian hasil belajar peserta didik yang diharapkan adalah peserta didik memperoleh nilai $\geq 70$ mencapai $\geq 60 \%$ pada akhir siklus. Target tersebut merupakan hasil pertimbangan dengan melihat KKM pada materi yang akan diajarkan yaitu 70 dan tingkat kesulitan materi serta kondisi peserta didik. Menurut Kunandar (2013) bahwa dalam penentuan batas pencapaian ketuntasan yang paling realistik adalah ditetapkan oleh sekolah atau daerah. Untuk menghitung persentase hasil belajar matematika peserta didik, digunakan rumus berikut.

Keterangan :

$$
\% C=\frac{C s}{N} \times 100 \%
$$

$\% \mathrm{C}=$ Persentase peserta didik yang mendapat nilai $\geq 70$

Cs = Jumlah peserta didik yang mendapat nilai $\geq 70$

$\mathrm{N} \quad=$ Jumlah peserta didik

\section{HASIL PENELITIAN DAN PEMBAHASAN}

Pada penelitian tindakan kelas ini dirancang pembelajaran dengan PBL berbasis $Q R$-Code. Kegiatan yang sudah dilakukan adalah sebanyak dua siklus di 
mana masing - masing siklus terdiri dari satu KD. KD pertama yaitu mengintepretasi persamaan dan pertidaksamaan nilai mutlak dari bentuk linear satu variabel dengan persamaan dan pertidaksamaan linear Aljabar lainnya dan KD kedua adalah menjelaskan dan menentukan penyelesaian pertidaksamaan rasional dan irasional satu variabel. Setiap siklus dilaksanakan sebanyak empat pertemuan. Setiap pertemuan mempunyai alokasi waktu 2 jam pelajaran atau $2 \times 45$ menit.

\section{Siklus I}

Pelaksanaan siklus I berjalan selama empat kali pertemuan. Tahapan siklus I dijelaskan sebagai berikut.

a) Perencanaan

Kegiatan yang dilakukan pada tahap perencanaan ini adalah mempersiapkan segala perangkat pembelajaran yang diperlukan. Selain itu, ditentukan juga materi yang sesuai dengan KD pertama. Materi untuk siklus I yaitu nilai mutlak, persamaan nilai mutlak linear satu variabel dan pertidaksamaan nilai mutlak linear satu variabel. Perangkat pembelajaran yang disiapkan adalah RPP untuk empat pertemuan disertai dengan LKPD untuk masing-masing pertemuan tersebut. Pembelajaran yang dirancang dan dicantumkan di RPP juga disesuaikan dengan Problem Based Learning (PBL) yang terdiri dari enam tahapan pada sintaknya. Selain itu, disisipkan juga beberapa QR-Code pada masing-masing LKPD di setiap pertemuan. Pada tahap ini juga dibuat lembar soal tes yang akan diujikan diakhir siklus I atau pada pertemuan kelima.

b) Pelaksanaan
Pada tahap ini dilakukan penerapan PBL dengan $Q R$-Code yang sudah dipersiapkan sebelumnya. Kegiatan pembelajaran dilakukan sebanyak empat pertemuan. Pertemuan pertama dilaksanakan pada Hari Senin Tanggal 23 Juli 2018, pertemuan kedua dilaksanakan pada Hari Selasa Tanggal 24 Juli 2018, pertemuan ketiga dilaksanakan pada Hari Senin Tanggal 30 Juli 2018 dan pertemuan keempat dilaksanakan pada Hari Selasa Tanggal 31 Juli 2018. Setelah dilakukan pembelajaran sebanyak empat pertemuan, maka di pertemuan kelima dilakukan tes untuk mengetahui hasil belajar peserta didik untuk siklus I. Data hasil belajar tersebut yang dijadikan tolak ukur keberhasilan pada siklus I.

c) Pengamatan

Pengamatan dilakukan secara bersamaan dengan tahap pelaksanaan. Pengamatan dilakukan pada setiap pertemuan. Secara umum pelaksanaan PBL berbasis $Q R$-Code dapat berjalan dengan baik. Guru dapat memberikan permasalahan di awal pembelajaran khususnya masalah terkait dunia nyata. Kekurangan dalam siklus I ini adalah pada pertemuan ketiga, di mana materi yang disampaikan adalah terkait dengan menggambar grafik nilai mutlak. Pada pertemuan ketiga tersebut, guru kurang memberi permasalahan terkait dunia nyata. Hal ini karena terdapat kesulitan dalam menemukan masalah yang sesuai. Namun demikian, penggunaan QR-Code tetap berjalan dengan baik. Pengamatan paling utama dilakukan terhadap hasil belajar matematika peserta 
didik. Hasil belajar tersebut dilihat dari nilai hasil belajar yang diperoleh setelah pemberian tes pada pertemuan kelima. Hasil dari tes siklus I ditampilkan pada Tabel 3.

Tabel 3. Hasil Belajar Siklus I

\begin{tabular}{|c|c|c|c|}
\hline KKM & Keterangan & $\begin{array}{c}\text { Jumlah Peserta } \\
\text { Didik }\end{array}$ & Persentase \\
\hline$\geq 70$ & Tuntas & 17 & 47,22 \\
\hline$<70$ & Tidak Tuntas & 19 & 52,78 \\
\hline \multicolumn{2}{|c|}{ Total } & 36 & $100 \%$ \\
\hline
\end{tabular}

\section{d) Refleksi}

Setelah pelaksanaan siklus I selesai, selanjutnya dilakukan kegiatan refleksi. Berdasarkan data yang telah diperoleh, diketahui bahwa peserta didik yang mendapatkan nilai sesuai KKM yaitu $\geq 70$ terdapat 17 peserta didik atau baru mencapai $47,22 \%$. Hal ini menunjukkan bahwa indikator keberhasilan yang direncanakan belum tercapai. Sehingga perlu dilakukan siklus II dengan memperhatikan kekurangankekurangan yang ada di siklus I. Beberapa hal yang menjadi masalah pada siklus I adalah:

1) Peserta didik belum begitu banyak diberi latihan. Latihan pada LKPD baru berisi dua atau tiga soal. Soal-soal itupun sebagian besar berisi masalah nyata sehingga peserta didik terkadang masih kebingungan dalam membuat model matematika yang sesuai.

2) Seluruh peserta didik sebenarnya mempunyai smartphone. Namun demikian, masih banyak peserta didik yang tidak membawa smartphone untuk digunakan dalam pembelajaran.
3) Koneksi internet juga menjadi salah satu kendala yang ditemukan.

\section{Siklus II}

Untuk memperbaiki beberapa kekurangan atau kendala yang ditemukan pada siklus I maka dilakukan siklus II. Sama halnya dengan siklus I, maka siklus II juga dilaksanakan dengan tahapan perencanaan, pelaksanaan, pengamatan dan refleksi. Untuk siklus II materi yang diambil berada di KD kedua yaitu menjelaskan dan menentukan penyelesaian pertidaksamaan rasional dan irasional satu variabel.

a) Perencanaan

Setelah dilaksanakan refleksi pada siklus I maka dilakukan beberapa perbaikan perencanaan tindakan untuk di siklus II. Perbaikan yang dilakukan diantaranya adalah dengan memperbanyak latihan yang diberikan kepada peserta didik. Masalah nyata terkait materi tetap diberikan karena bagian dari PBL, namun demikian masalah tersebut dibatasi hanya satu saja di awal pembelajaran untuk mengarahkan peserta didik ke materi yang akan diajarkan. Perbaikan selanjutnya adalah dengan lebih mengarahkan peserta didik agar membawa 
smartphone atau laptop dalam pembelajaran di kelas, hal ini untuk lebih membantu peserta didik dalam mencari segala informasi dan sumber belajar lainnya. Untuk kendala koneksi internet, jaringan Wifi tetap dibuka ditambah pengarahan bagi peserta didik yang mempunyai kuota internet untuk dapat menggunakannya agar jaringan wifi tidak begitu berat. Selain itu, guru juga memberikan wifi melalui ponselnya untuk menambah jaringan internet. Persiapan lainnya sama dengan siklus I yaitu perangkat pembelajaran berupa RPP dengan PBL di dalamnya serta LKPD yang disertai QR-Code. Kegiatan siklus II dilakukan sebanyak lima pertemuan dengan materi umum persamaan dan pertidaksamaan kuadrat, rasional dan irasional.

b) Pelaksanaan

Kegiatan tahap ini juga secara umum sama dengan di siklus I yaitu penerapan PBL dengan QR-Code yang sudah dipersiapkan sebelumnya. Kegiatan pembelajaran dilakukan sebanyak lima pertemuan yang dimulai dari pertemuan keenam karena melanjutkan dari siklus I. Pertemuan keenam dilaksanakan pada Hari Senin Tanggal 13 Agustus 2018, pertemuan ketujuh dilaksanakan pada Hari Senin Tanggal 20 Agustus 2018, pertemuan kedelapan dilaksanakan pada Hari Selasa Tanggal 21 Agustus 2018, pertemuan kesembilan dilaksanakan pada Hari Senin Tanggal 27 Agustus 2018 dan pertemuan kesepuluh dilaksanakan pada Hari Selasa Tanggal 28 Agustus 2018.

c) Pengamatan

Pengamatan juga dilakukan secara bersamaan dengan tahap pelaksanaan. Untuk siklus II, secara umum pelaksanaan PBL berbasis $Q R$-Code juga dapat berjalan dengan baik. Guru selalu memberikan permasalahan di awal pembelajaran untuk dapat memberikan gambaran terkait manfaat materi di dalam dunia nyata yang memungkinkan peserta didik untuk lebih termotivasi. Hasil belajar tersebut dilihat dari nilai hasil belajar yang diperoleh setelah pemberian tes pada pertemuan kesebelas. Hasil dari tes siklus II ditampilkan pada Tabel 4 .

Tabel 4. Hasil Belajar Siklus II

\begin{tabular}{|c|c|c|c|}
\hline KKM & Keterangan & $\begin{array}{c}\text { Jumlah Peserta } \\
\text { Didik }\end{array}$ & Persentase \\
\hline$\geq 70$ & Tuntas & 23 & $63,89 \%$ \\
\hline$<70$ & Tidak Tuntas & 13 & $36,11 \%$ \\
\hline \multicolumn{2}{|c|}{ Total } & 36 & $100 \%$ \\
\hline
\end{tabular}

\section{d) Refleksi}

Setelah pelaksanaan siklus II selesai, selanjutnya dilakukan kegiatan refleksi. Berdasarkan data yang telah diperoleh, diketahui bahwa peserta didik yang mendapatkan nilai sesuai KKM yaitu $\geq 70$ terdapat 23 peserta didik atau sudah mencapai $63,89 \%$ dan yang belum tuntas sebanyak $36,11 \%$. Meskipun masih terdapat peserta didik yang belum mencapai KKM, namun berdasarkan indikator keberhasilan yang sudah 
direncanakan, pada siklus II ini sudah dapat memenuhi indikator tersebut yaitu setidaknya $60 \%$ peserta didik yang mencapai KKM.

Berdasarkan hasil yang telah diperoleh, diketahui bahwa hasil belajar peserta didik mengalami peningkatan jika dilihat berdasarkan persentase ketercapaian KKM. Pada siklus I peserta didik yang mencapai KKM sebanyak 47,22\% dan pada siklus II meningkat menjadi $63,89 \%$. Meskipun masih terdapat peserta didik yang belum mencapai KKM, namun hal ini tetap dapat membuktikan bahwa penerapan PBL berbasis $Q R$-Code dapat meningkatkan hasil belajar peserta didik. Ketercapaian tersebut dapat divisualisasikan pada Gambar 2.

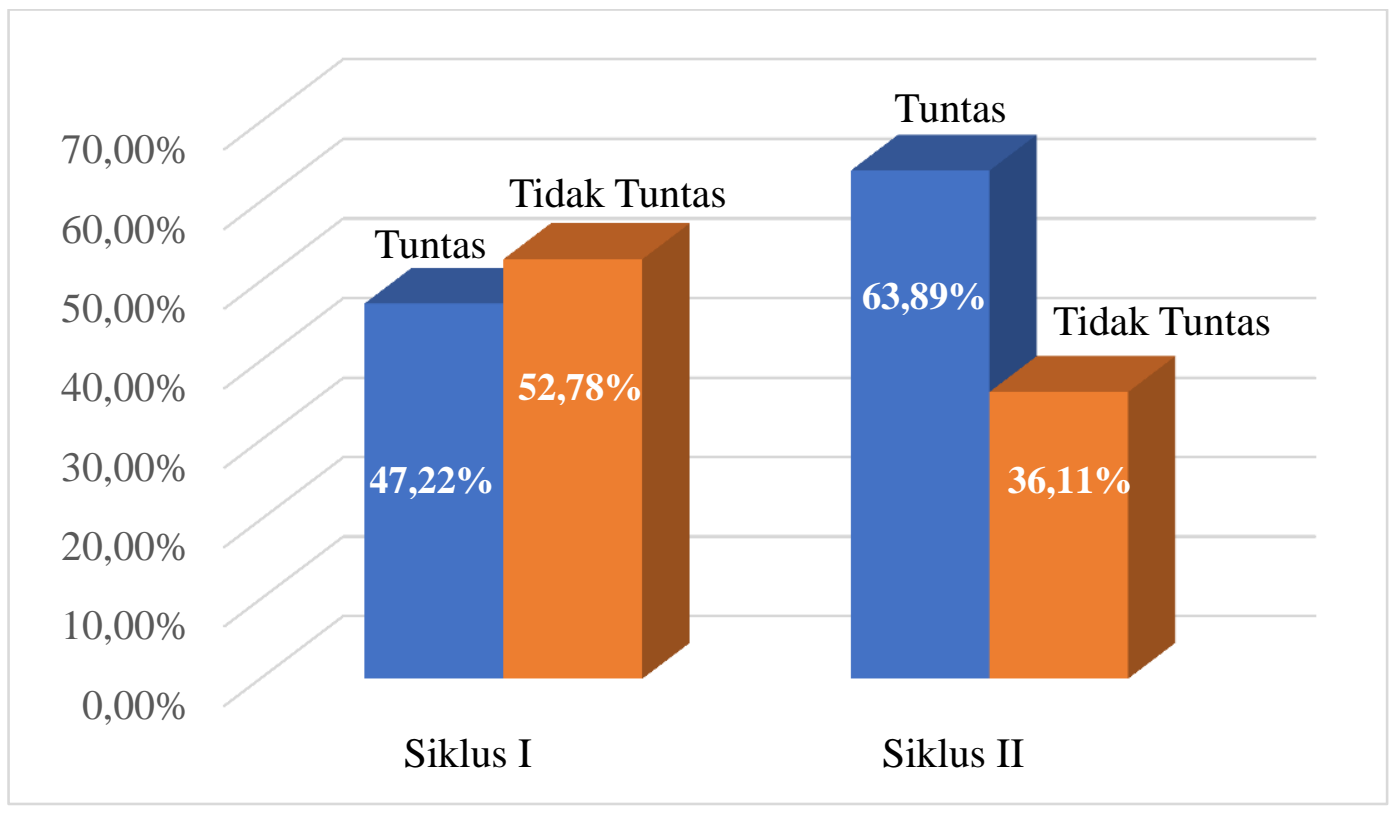

Gambar 2. Ketercapaian Hasil Belajar Matematika Peserta Didik

Pada penerapannya, Problem Based Learning (PBL) memberikan gambaran awal mengenai manfaat mempelajari suatu materi. Gambaran tersebut tersampaikan melalui masalah dunia nyata terkait dengan materi yang akan diajarkan. Masalah disajikan di awal pembelajaran dan selanjutnya mengarahkan peserta didik untuk menyelesaikan permasalahan tersebut dengan materi yang dipelajari. Hal ini tentu saja membuat peserta didik langsung terfokus kepada masalah nyata tersebut dan dapat menimbulkan rasa ingin tahu tentang cara penyelesaiannya. Masalah nyata tersebut juga merupakan dasar dari PBL itu sendiri di mana PBL berasal dari bidang kedokteran di Universitas McMaster yang muncul agar mahasiswa di Universitas tersebut dapat menyelesaikan masalah yang lebih relevan di kehidupan nyata (Schmidt, 2014).

Namun demikian, penerapan PBL ini memang belum begitu sempurna dan dapat ditunjukkan melalui hasil belajar peserta didik yaitu terdapat $36,11 \%$ peserta didik belum mencapai KKM. Penerapan PBL sebenarnya sudah cukup baik dan semua langkah atau sintak PBL sudah berjalan, namun memang dalam suatu kelas tentu mempunyai peserta didik dengan bermacam karakteristik termasuk kelas $\mathrm{X}$ MIPA 3 SMAN 1 
Kotagajah. Beberapa peserta didik masih ada yang belum mengikuti pembelajaran dengan baik, misalnya terdapat peserta didik yang terlihat hanya sekedar ikut-ikutan dan terlihat bermalas-malasan dalam diskusi kelompok, tentu hal tersebut perlu menjadi perhatian guru untuk kedepannya. Guru ataupun peneliti harus pandai membawa suasana agar tetap nyaman, karena model PBL ini cenderung dimanfaatkan siswa yang malas hanya ikut serta tanpa partisipasi dalam kelompok (Kamid, Anggereini, \& Muhtadin, 2018). Selain itu, guru juga dapat menambahkan atau menyisipkan kegiatan-kegiatan yang bersifat permainan untuk membuat peserta didik lebih bersemangat dan lebih berkonsentrasi. Kegiatan tersebut hanya sebagai upaya untuk mengatasi permasalahan peserta didik yang terlihat malas, karena pada dasarnya menurut Maulidia (2009) jika berkaca dari teori Brofenbrenner yang berparadigma lingkungan (ekologi), teori tersebut menyatakan bahwa perilaku seseorang (termasuk perilaku malas belajarpada anak) tidak berdiri sendiri, melainkan merupakan dampak dari interaksi orang yang bersangkutan dengan lingkungan di luar diri individu.

Pada penelitian tindakan kelas ini juga berbasis teknologi yaitu dengan adanya penggunaan $Q R$-Code. Peserta didik dapat memperoleh tambahan informasi secara cepat melalui pemanfaatan $Q R$-Code yang tertera pada LKPD. Informasi ini yang digunakan untuk membantu peserta didik dalam mengikuti pembelajaran PBL khususnya pada tahap PBL yaitu mengorganisasi peserta didik untuk belajar dan membimbing penyelidikan individual maupun kelompok. $Q R$-Code tersebut mengarahkan peserta didik ke suatu halaman web yang berisi materi atau halaman yang berisi video terkait permasalahan atau materi tambahan lainnya. Penggunaan $Q R$-Code ini yang dirasakan membuat rasa kebosanan peserta didik menjadi berkurang karena dapat menggunakan smartphone atau laptop untuk menjelajah dunia maya atau internet.

Penggunaan internet dapat berpengaruh baik terhadap proses pembelajaran dan terhadap hasil pembelajaran (Diana, 2016). Selain itu pemanfaatan internet dapat berpengaruh positif terhadap kegiatan belajar peserta didik (Tomo \& Utami, 2016). Khusus untuk $Q R$-Code sendiri dapat berdampak positif terhadap suatu pembelajaran di kelas (Mustakim et al., 2013).

\section{KESIMPULAN DAN SARAN}

Berdasarkan hasil penelitian tindakan kelas yang telah dilakukan, maka diperoleh kesimpulan bahwa penerapan Problem Based Learning (PBL) berbasis QR-Code dapat meningkatkan hasil belajar matematika peserta didik kelas X MIPA 3 SMA N 1 Kotagajah. Hal ini ditunjukkan dari perolehan persentase nilai pada siklus I mencapai $47,22 \%$ dan pada siklus II meningkat menjadi $63,89 \%$.

Berdasarkan penelitian yang telah dilakukan, maka beberapa saran yang dapat diberikan diantaranya dalam menerapkan Problem Based Learning (PBL), perlu menyesuaikan juga dengan materi yang akan diajarkan, karena beberapa materi di matematika ada yang sulit untuk dikaitkan dengan masalah nyata. Selain itu untuk menggunakan QR-Code, sebaiknya juga memperhatikan kualitas internet dan isi dari halaman web yang dimuat di $Q R$ Code. Jika internet tidak berjalan dengan baik, maka dapat menganggu pelaksanaan pembelajaran tersebut. 
DOI: https://doi.org/10.24127/ajpm.v8i1.1894

\section{DAFTAR PUSTAKA}

Anshori, S. (2018). Pemanfaatan Teknologi Informasi dan Komunikasi sebagai Media Pembelajaran. Civic-Culture: Jurnal Ilmu Pendidikan PKn Dan Sosial Budaya, 2(1), 88-100.

Botty, H. M. R. H., Shahrill, M., Chong, M. S. F., Li, H.-C., \& Jaidin, J. H. (2016). The Implementation of Problem-Based Learning (PBL) in a Year 9 Mathematics Classroom: A Study in Brunei Darussalam. International Research in Education, 4(2), 34-47.

BPSDMPK, PMP, \& Kemendikbud. (2014). Materi Pelatihan Implementasi Kurikulum 2013 Tahun 2014. Jakarta: Kemdikbud.

Diana. (2016). Studi Deskriptif Tentang Pemanfaatan Internet sebagai Media Pembelajaran. Matrik, 18(1), 77-88.

Hosnan, M. (2014). Pendekatan Saintifik dan Kontekstual dalam Pembelajaran Abad 21: Kunci Sukses Implementasi Kurikulum 2013. Bogor: Ghalia Indonesia.

Iswan dan Herwina. (2018). Penguatan

Pendidikan Karakter Perspektif Islam dalam Era Millenial IR. 4.0. Makalah dipresentasikan Seminar Nasional Pendidikan Era Revolusi, Universitas Muhammadiyah Jakarta, Indonesia.

Kamid, K., Anggereini, E., \& Muhtadin, M. (2018). Penerapan Model Problem Based Learning untuk Meningkatkan Pemahaman Konsep Matematika Ditinjau dari Multiple Intelligences Siswa. Aksioma: Jurnal Program Studi Pendidikan Matematika, 7(2), 192-200.

Kunandar. (2013). Penilaian Autentik. Jakarta: Rajagrafindo Persada.

Marzoan. (2014). Peran Teknologi Informasi dan Komunikasi untuk
Meningkatkan Kualitas Pembelajaran dalam Perspektif Kurikulum 2013. Jurnal Inovasi dan Teknologi Pembelajaran, 1(1), 81-90.

Maulidia, R. (2009). Problem Malas Belajar Pada Remaja (sebuah Analisis Psikologis). At-Ta'dib, 4(2), 129-144.

Mustakim, S., Walanda, D. K., \& Gonggo, S. T. (2013). Penggunaan Qr Code dalam Pembelajaran Pokok Bahasan Sistem Periodik Unsur pada Kelas X SMA Labschool Untad. Jurnal Untad, 2 (2), 215-221.

Novita, R., Prahmana, R. C. I., Fajri, N., \& Putra, M. (2018). Penyebab Kesulitan Belajar Geometri Dimensi Tiga. Jurnal Riset Pendidikan Matematika, 5(1), 1829.

Padmavathy, R. D., \& Mareesh.K. (2013). Effectiveness of Problem Based Learning in Mathematics. International Multidisciplinary EJournal, 2(1), 45-51.

Priatmoko, S. (2018). Memperkuat Eksistensi Pendidikan Islam di Era 4.0. Ta"Lim: Jurnal Studi Pendidikan Islam, 1(2), 1-19.

Sanjaya, W. (2010). Strategi Pembelajaran Berorientasi Standar Proses Pendidikan. In System. Jakarta: Prenada Media Group.

Schmidt, H. G. (2014). A Brief History of Problem-Based Learning. Dalam O' Grady, G., Yew, E.H.J., Goh, K, P, L., \& Schmidt, H. G (Eds.), One-Day, One-Problem: An Approach to Problem-based Learning (pp. 21-40). Singapore: Springer.

Sharma, V. (2013). QR Codes in Education - A Study on Innovative Approach in Classroom Teaching. IOSR Journal of Research \& Method in Education 
DOI: https://doi.org/10.24127/ajpm.v8i1.1894

(IOSRJRME), 3(1), 62-70.

Suharsimi, A. (2010). Prosedur Penelitian: Suatu Pendekatan Praktik (Edisi Revisi). In Jakarta: Rineka Cipta.

Kintoko,. Sujadi, I., \& Dewi, R. S. S. (2015). Pengembangan Media Pembelajaran Matematika Berbantuan Komputer dengan Lectora Authoring Tools pada Materi Bangun Ruang Sisi Datar Kelas VIII SMP/MTS. Jurnal Elektronik Pembelajaran Matematika, 3(2), 167-178.

Suwardana, H. (2018). Revolusi Industri 4.0 Berbasis Revolusi Mental. Jurnal Ilmiah Teknik dan Manajemen Industri, 1(2), 102110.

Tomo, S., \& Utami, Y. R. W. (2016). Pengaruh Pemanfaatan Internet terhadap Kegiatan Belajar Siswa SMA di Surakarta. Jurnal Ilmiah Sinus, 14(1), 21-32.

Wayase, U. R. (2015). QR Code: An Innovative Teaching Learning Tool. International Journal of Innovative Science, Engineering \& Technology, 2(7), 402-405.

Widyatiningtyas, R., Kusumah, Y. S., Sumarmo, U., \& Sabandar, J. (2015). The Impact of ProblemBased Learning Approach to Senior High School Students' Mathematics Critical Thinking Ability. IndoMS-JME, 6(2), 107116. 